法によってポーラロ分析を行なった結果，このものは壏化トリエ チル鉛であることがかかった。四エチル鉛の分解機满については いまだ十分明らかにされていないが，Razǔvaev ら独四エチル 鉛の液相熱分解の柕樓についてつぎのよに述べている。

$$
\begin{aligned}
& \left(\mathrm{C}_{2} \mathrm{H}_{5}\right)_{4} \mathrm{~Pb} \longrightarrow\left(\mathrm{C}_{2} \mathrm{H}_{5}\right)_{3} \mathrm{~Pb} \cdot+\mathrm{C}_{2} \mathrm{H}_{5} \cdot \\
& \left(\mathrm{C}_{2} \mathrm{H}_{5}\right)_{8} \mathrm{~Pb} \cdot+\left(\mathrm{C}_{2} \mathrm{H}_{5}\right)_{4} \mathrm{~Pb} \\
& \stackrel{\longrightarrow}{\longrightarrow}\left(\mathrm{C}_{2} \mathrm{H}_{5}\right)_{8} \mathrm{PbPb}\left(\mathrm{C}_{2} \mathrm{H}_{5}\right)_{8}+\mathrm{C}_{2} \mathrm{H}_{5} . \\
& 2\left(\mathrm{C}_{2} \mathrm{H}_{5}\right)_{8} \mathrm{~Pb} \cdot \longrightarrow\left(\mathrm{C}_{2} \mathrm{H}_{5}\right)_{3} \mathrm{PbPb}\left(\mathrm{C}_{2} \mathrm{H}_{5}\right)_{8} \\
& \left(\mathrm{C}_{2} \mathrm{H}_{5}\right)_{8} \mathrm{PbPb}\left(\mathrm{C}_{2} \mathrm{H}_{5}\right)_{3} \longrightarrow\left(\mathrm{C}_{2} \mathrm{H}_{5}\right)_{4} \mathrm{~Pb}+\left(\mathrm{C}_{2} \mathrm{H}_{5}\right)_{2} \mathrm{~Pb} \\
& \left(\mathrm{C}_{2} \mathrm{H}_{5}\right)_{2} \mathrm{~Pb} \longrightarrow \mathrm{Pb}+2 \mathrm{C}_{2} \mathrm{H}_{5} .
\end{aligned}
$$

直射日光照射による四エチル鉛の分解においてる中間に $\mathrm{Pb}_{2}$. $\left(\mathrm{C}_{2} \mathrm{H}_{3}\right)_{6}, \mathrm{~Pb}\left(\mathrm{C}_{2} \mathrm{H}_{5}\right)_{2}$ などが生成し，これと塩化エチルが反応し て塩化トリエチル鉛が生成したものと考えることができる。

\section{5 站ナトリウム合金と塭化エチルの反応残留物}

1 に述べたように, Pearsall は活性な鉛とくに鉛ナトリウム合 金とハロゲン化アルキルから四エチル鉛を合成する場合の副生鉛 とハロゲン化アルキルを作用させてて，四エチル鉛が好取率で得ら れると述べている。しかし，塩化エチル，具化エチルの場合は， ヨウ素を触媒としないとき沈応しないとしている。この活性鉛 そハロ.ゲン化アルキルから四エチル鉛の生成は, 当然ハロゲン化 鉛の副生をとすなうむのである。

$$
4 \mathrm{C}_{2} \mathrm{H}_{5} \mathrm{Cl}+3 \mathrm{~Pb} \longrightarrow \mathrm{Pb}\left(\mathrm{C}_{2} \mathrm{H}_{5}\right)_{4}+2 \mathrm{PbCl}_{2}
$$

著者は，ヨウ菜を触媒としないで鉛ナトリウム合金 $(\mathrm{PbNa})$ と 塭化エチルを反応させ，無水酢酸エチルで可溶物筫を除去した残 留固形物についてX線分析を行なったが，塩化鉛を検出すること

18) G. A. Razūvaev, N. S. Vyazankin, N. N. Vyshinskii,
Zhur. Obshchei Khim., 29, 3662(1959).

はできなかった。これは Pearsall がいったようにヨウ素を触媒 としないために塩化鉛が生成しないものであるか，あるいは一度 生成した填化鉛がつぎの式で示すように合金中のナトリウムと反 忘して鉛と塭化鉛となるものか明らかでない。

$\mathrm{PbCl}_{2}+2 \mathrm{Na} \longrightarrow \mathrm{Pb}+2 \mathrm{NaCl}$

以上述べたように著者は，

1) 各種の鉛ナトリウム合金と各種のハロゲン化エチルとから 四エチル鉛を生成するにあたって，エチルアルコール，触媒など を添加しない場合についてその反応性を系統的に調べ，反応がよ くすすむためには，八ロゲン化エチルが鉛ナトリウム合金の内部 に浸透することによって合金内部で反応が起り，合金ががきぜ によって砕けやすくなることが必要であると推諭した。

2 ）鉛ナトリウム合金と塭化エチルの反応生成物の中に塭化卜 リエチル鉛が存在することを明らかにした。

3 ) 直射日光照射のもとに四エチル鉛と塩化エチルを反応させ て塩化トリェチル鉛が得ら机，粗製の四エチル鉛と塩化エチルの 反応により同様に塩化トリェチル鉛が得られることを明らかにし た。

4 ）鉛ナトリウム合金と塩化エチルと反応させ四エチル鉛を生 成子る場合の残留固形物のX線分析を行なったが，程化鉛を検出 することができなかった。

終りに，本研究について御指導を晹わった京都大学理学部後藤 定造教授，ならびにX線分析について御協力を睗わった日本金属 工業株式会社川㱦工揚杉本正腾博士に対し，また本研究の発表を 許可された日本曾達株式会社当局に深く感謝いたします。

\title{
シキミ有毒成分アニサチンの誘導体ノルアニサチンの部分構造*1
}

(绍和 40 年 8 月 19 日受理)

$$
\text { 高田進・中村司朗·山田静之・平田義正*2 }
$$

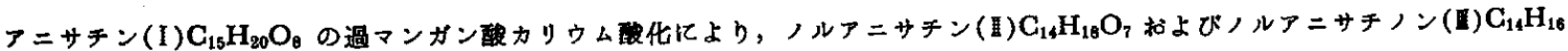

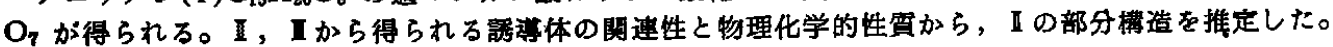

\section{1 緒言}

シキミ (Illicium Anisatum, Linnaeus.)の有毒成分の研究は，古 くは Eykman'〉による報告があるが, 1952 年, Lane らはは は でめてその成分を緑粋な結晶として単離し,アニサチン(anisatin) と命名している。Lane らは，同時にその分子式 $\mathrm{C}_{15} \mathrm{H}_{20} \mathrm{O}_{8}$ と部 分構造を報告しているが，その後の報告は見あたらない。

著者らは，アニサチンが分子式で示されるように比較的多くの

*1との報文を“シキミ有毦成分の研究(第1 報)”とする。

*2 Susumu Takada, Shiro Nakamura, Kiyoyuki Yamada, Yoshimasa HrRATA 名古屋大学理学部化学教室, 名古 虽市干租区不老畹

1) J. F. Eykman, Pharm. J. and Trans., 11, 1046(1881).

2) J. F. Lane, W. T. Kock, N. S. Leeds, G. Gorin, J. Am. Chem. Soc., 74, 3211(1952).
酸素原子をもつことに興味を持ち，その構造研究を行なった。ア ニサチンの抽出の際, 新しくアニサチンより酸离原子のI個少な いデオキシアニサチン(仮称), $\mathrm{mp} 234^{\circ} \sim 236^{\circ} \mathrm{C}, \mathrm{C}_{15} \mathrm{H}_{20} \mathrm{O}_{7}$ を結 晶として単離した。デオキシアニサチンは，通常アニサチンとの 混合物として得られ，その分嶉は困難であった。アニサチンは， 種々の有機溶媒に対する溶解度が覀く*3，アニサチン自身につい てはかぎられた反応以外はできないので，その酸化生成物ノルア ニサチンの構造を初めに研究することにした。

\section{2 ノルアニサチンの部分構造}

\section{1 ノルアニサチンの性旗}

アニサチン(I ) $\mathrm{C}_{15} \mathrm{H}_{20} \mathrm{O}_{8}$ を含水酢酸中，過マンガン酸カリウ

*3エーテル，クロロホルムには任とんど溶けない，アセト ンに対する溶解度も NMR スペクトル澌定可能な慾解 度かはかった。 
ムで酸化すると，ノルアニサチン(I), $\mathrm{mp} 163^{\circ} \sim 164^{\circ} \mathrm{G}, \mathrm{G}_{14}$. $\mathrm{H}_{18} \mathrm{O}_{7}$ および,ノルアニサチノン(I), mp $213^{\circ} \sim 215^{\circ} \mathrm{C}, \mathrm{C}_{14} \mathrm{H}_{16}$. $\mathrm{O}_{7}$ が得られる。ノルアニサチン $(\mathbb{I})$ は中性物質であり，赤外吸 収スペクトルにおいて 1832 と $1778 \mathrm{~cm}^{-1}$ の 2 本のカルボニル吸 収を有し，アニサチン(I)のカルボニル吸収 $\left(1833\right.$ と $\left.1735 \mathrm{~cm}^{-1}\right)$ とくらべると，低波数側の吸收が䄪 $40 \mathrm{~cm}^{-1}$ だけ高波数側にシ フトしている。ノルアニサチン（II）の NMR スペクトル(図 1) は $1.03 \mathrm{ppm} * 4$ に二級メチル基のシグナル(3H，二重線， $J=6.5$ cps), $1.50 \mathrm{ppm}$ に三級メチル基のシグナル $(3 \mathrm{H}$ ，単一線)を有し， $4.22 \mathrm{ppm}$ K $-\mathrm{CH}_{2}-\mathrm{O}-$ と考えられる水素 2 個分の単一線が存在 する。さらに, 重水添加法により消失するシグナルが氷素 3 個分 あることから水酸基が 3 個存在していることがわかる。．

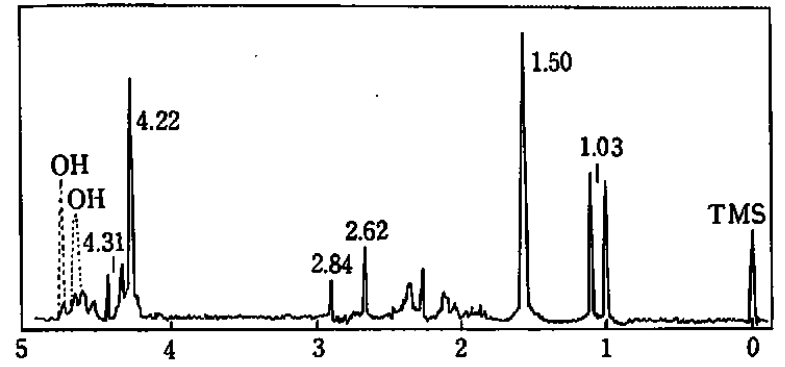

(ppm)

重クロロホルム中, $60 \mathrm{Mc}$ ，テトラメテルシランからの ppm.

図 1 ノルアニサチン(1)の NMR スペクトル

\subsection{1,2-グリコールの存在}

ノルアニサチン(I) の過ヨウ素酸滴定および四酹酸鉛滴定は， ともに $1 \mathrm{~mol}$ を消費してとまる。またIIはスゲンと作用して， 分子内孷酸エステル(IV)， $\mathrm{mp} 236^{\circ} \sim 238^{\circ} \mathrm{C}, \mathrm{C}_{15} \mathrm{H}_{18} \mathrm{O}_{8}$ を与え る。これらの事実は1,2-グリコールの存在を示す。1を四酢酸 鉛酸化すると,ケトアルデヒド(V), $\mathrm{mp} 191^{\circ} \sim 192^{\circ} \mathrm{C}, \mathrm{C}_{14} \mathrm{H}_{16} \mathrm{O}_{7}$ を与え，これをさらに酸化するとケト酸(U)， mp $152^{\circ} \sim 154^{\circ} \mathrm{C}$, $\mathrm{C}_{14} \mathrm{H}_{16} \mathrm{O}_{8}$ を生ずる。このととから 1,2-グリコールは，二級およ。 び三級の水酸基からできているととがわかる。

Iのモノアセタート(汭), mp $186^{\circ} \sim 188^{\circ} \mathrm{C}, \mathrm{C}_{16} \mathrm{H}_{20} \mathrm{O}_{8}$ は四酢 酸鉛を消費しないことから，1,2-グリコールの二級水酸基がア セチル化されていることがわかるが，このモノアセタート(Y)の NMR スペクトルには， $5.67 \mathrm{ppm}$ に四重線(1H，J=7.0, 9.5 cps)が存在するが，これはIの NMR スペクトルで $4.60 \mathrm{ppm}$

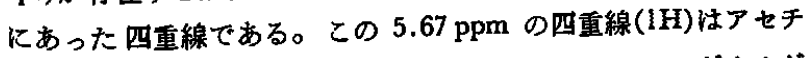
ル基をむつ炭素についた水素のシグナルであり，このシグナルが 四重線に分裂していることから，アセチル基をむつ炭素の隣接炭 素には 2 個の水素が存在することがわかる。ゆえにIの部分構造 として,$-\mathrm{CH}_{2}-\mathrm{CH}(\mathrm{OH})-\mathrm{C}(\mathrm{OH})$ の原子団が存在する。

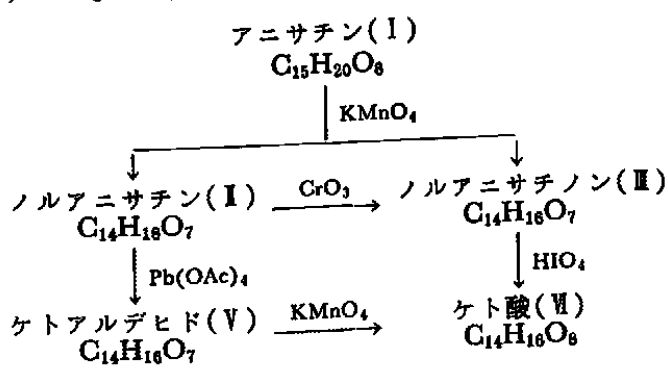

*4 化学シフトはすべてテトラメチルシランからの ppm で 表わしてある.

\section{3 岸索 5 只環の存在}

アニサチン(I)を過マンガン酸カリウム酸化すると，前述のよ

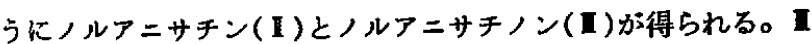
はIを酢酸中無水ク口ム酸酸化しても得られる。峛は四醀酸鉛の 消費速度が、にくらべて非常に遅いので，1,2-グリコールの二級 水酸基が酸化されたケト体と予想されるが，【を過ヨウ素酸で酸 化して得られるケト酸は，前述のIを四酢酸鉛で酸化して得られ るケトアルデヒド(V)をつういて遇マンガン酸カリウム酸化して 得られるケト酸(U)と一致する事実からむ，1,2-グリコールの二 級水酸基が酸化されていることが確かめられる。

郝吸収スペクトルで，Iにはなくて【にのみ存在する 1754 $\mathrm{cm}^{-1}$ のカルボニル吸収は，その吸収領城から5 員環ヶトンの吸

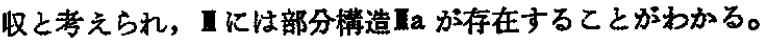<smiles>C[C@H]1CC(=O)[C@](C)(O)C1(C)C</smiles>

(III)

\section{$2.4-\mathbf{C}-\mathrm{CH}_{2}-\mathrm{C} H-O-$ 原子団の存在}

ノルアニサチン(耳)の NMR スペクトルにおいて， 2.62 と $2.84 \mathrm{ppm}$ のシグナルは $\mathrm{AB}$ 型3の左半分のようすをしているが, 右の部分はさらに分裂していると予想されたのでスピンのデカッ プリングを行なって確かめた。 $4.31 \mathrm{ppm}$ の二重線 $(J=5.5 \mathrm{cps})$ の位置で共潟高周波を照射すると，2.36 ppm にあった 2 本の緗 ( $J=5.5 \mathrm{cps}$ )が 1 本になる(図 2 , 矢印)。このシグナルは AB 型 のシグナルのうちのI本と考えられる。右端に出るべき $\mathbf{A B}$ 型シ グナルの一部は他のシグナルと重なって明らかでないが, 後述の ブロムノルアニサチノン(V) のNMRスペクトルでは明膫に現わ れ，この解釈が正しいことが示された。この $\mathrm{AB}$ 型のシグナル(2 H) のスピン結合定数 $\left(J_{\mathrm{AB}}=13.5 \mathrm{cps}\right)$ の大きいことから， gem水素のカップリングと考えられる。さらに AB 型シグナルの一方 が低磁場(4.31 ppm)の水泰とカップリングしているので, 部分棈 造として - $\mathbf{I}_{1}^{\mathbf{C}}-\mathrm{CH}_{2}-\mathrm{C} \mathrm{CH}-\mathrm{O}-$ - 原子団が存在すると考えられる。

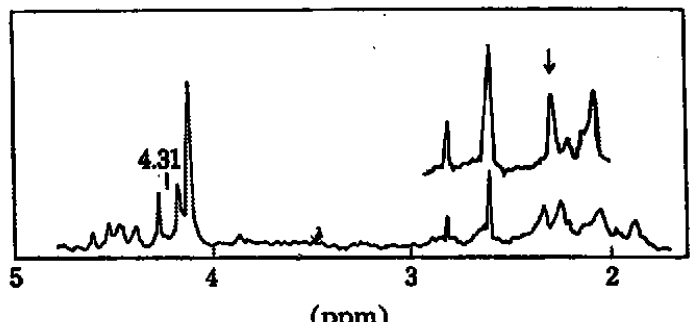

(ppm)

承クロロホルム中, $60 \mathrm{Mc}$, テトラメチルシランからの ppm.

図 2 ノルアニサチン(I)のデカップリング

\section{5 ブロムノルアニサチノンの NMR スペクトルにおける全} 水莱原子の解析

ノルアニサチノン $(\mathbf{I})$ に醀酸中，具素を作用させるとブロムノ ルアニサチノン(Vi) $, \operatorname{mp~} 207^{\circ} \sim 211^{\circ} \mathrm{C}, \mathrm{G}_{14} \mathrm{H}_{15} \mathrm{O}_{2} \mathrm{Br}$ が得られ る。この物質は】のカルボニル吸収 $1754 \mathrm{~cm}^{-1}$ (赤外吸取スペク

3) たとえば, L. M. Jackman, “ Applićations of Nuclear Magnetic Resonance Spectroscopy in Organic Chemistry", Pergamon Press, London(1959)p. 89. 
トル)が $1770 \mathrm{~cm}^{-1}$ に移動していることからか，5 員環ヶトンの

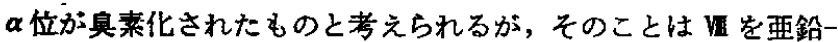
酷酸赺理すると旧むどることから確かめられる。

ブロムノルアニサチノン(V)の NMR スペクトル(四 3 )にお いて, $1.25 \mathrm{ppm} の 二$ 重線 $(J=7.0 \mathrm{cps}, 3 \mathrm{H})$ は二級メチル基であ り，1.60 ppm の単一線 $(3 \mathrm{H})$ は三級メチルのシグナルである。 $2.90 \mathrm{ppm}$ の単一線 (1H) と $5.8 \mathrm{ppm}$ の幅広いシグナル(1H)は, 重水添加により消失することからともに水酸基と考えられる。

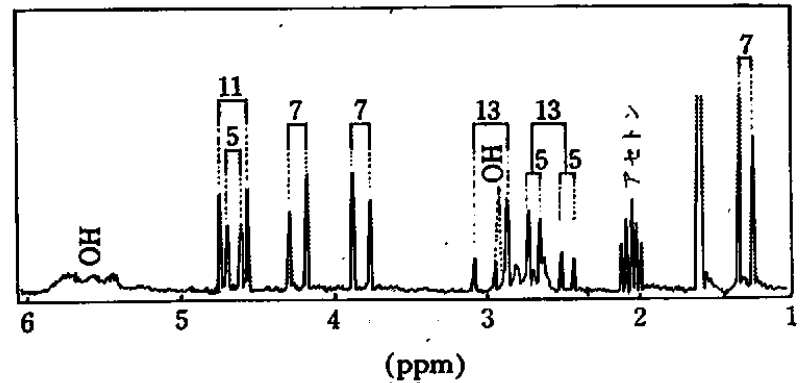

重アセトン中, $60 \mathrm{Mc}$, テトラメチルシランからの ppm.

因 3 ブロムノルアニサチノン(WI)の NMR スペクトル

$4.02 \mathrm{ppm}$ の四重線 $(2 \mathrm{H}, J=7.0 \mathrm{cps})$ は $\mathrm{AB}$ 型であり, その化 学シフトから酸絮をるつ炭素についた水素のシグナルと考えられ

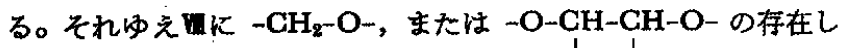
ていることがわかるが,この四重線のスピン゙スピン結合定数は, ノルアニサテンモノアセタート(U)からの誘導体らにおいて, 13.5 cps になり, 上記二つの可能性のうち, 後者のスピンースピン結合 定数としては大きすきること，またノルアニサチン（1）やノルア ニサチンモノアセタート(口)では, このシグナルが鋭い単一線で 現われることから- $\mathrm{CH}_{2}-\mathrm{O}-$ が妥当と考えられる。

2.4〜3.1 ppm の多重線(2H)と $4.65 \mathrm{ppm}$ の四重線(1H)で典 型的な $\mathrm{ABX}$ 型ののシグナルを 呈している $\left(J_{\mathrm{AB}}=13.0 \mathrm{cps}, J_{\mathrm{AX}}\right.$

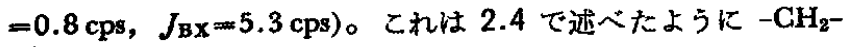
-安H-O- 部分の水素によるシグナルである。

$4.75 \mathrm{ppm}$ に存在する二重線 $(1 \mathrm{H}, J=11.0 \mathrm{cps})$ は,ノルアニサ チン（I）の NMR スペクトルにはないシグナルであり，その化 学シフトから鼻素をむつ炭素についた水素のシグナルである。こ のシグナルが二重線に出ていることから, 臭秦をもつ炭素の隣接 炭素には 1 個の水素が存在することがかかるが, 全水素原子 15 個のうち 14 個まで解析されていることを考え合わせると，この 水素(奥素をむつ炭素の器接炭素についた水菜)は，二級メチルと むカップリングして 2.2〜3.2 ppm にひろく広がっていると考え られる。それゆえ二級メチル基の位置も必然的に定末る。

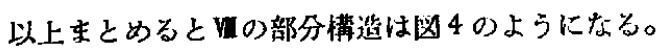<smiles>CC(COOO)CC(C)CC(C)(C)C</smiles>

因 4 四の部分構造

4) R. N. Jones, D. A. Ramsay, F. Herling, K. Dobriner, J. Am. Chem. Soc., 74, 2827(1952).

5) 中村, 山田, 平田, 日化, 87, 171(1966).

6) 文嘢 3) $の$ p. 90 .

\section{6 ノルアニサチン(II)の部分篧造}

ブロムノルアニサチノン (UII)の部分橉泚から推諭すると，ノル アニサチン(II)の部分满造は図 5 のとおりになる。

5 員罢部分の構造はアニサチン（I）を诺硫酸中でクロム酸酸化 すると,メチルコハク酸が得られることからも支持される。

1,2-グリコールに含まれない水酸基が三級であることは，つぎ の事実から推定される。1,2-グリコールを炭酸エステルとして保

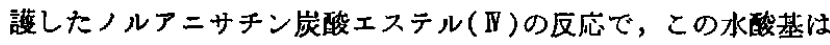
無水䣫酸ーピリシン中で加温してむアセチル化されないし，強い 条件でも酸化されない。

さらに, I の亦外吸収スペクトルに 1832 と $1778 \mathrm{~cm}^{-1}$ の 2 本 のカルボニル吸取があることから，2個のカルボニルが存在して いる。

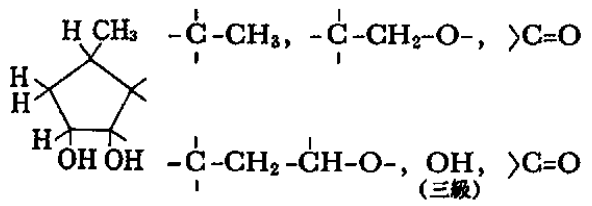

図 5 Iの部分棰造式

\section{3 実跧 の 部}

\section{1 アニサチン, デオキシアニサチンの抽出}

3.1 .1 脱 脂: シキミの種子を粉碑機でつぶすと種子の油の ため外見は湿ったような粉末になる。この粉末に 加え，ときどきかきませ $2 \sim 3$ 日室温放置して減圧口過する。乙 の脱脂の操作を 3 回くり返す。

3.1 .2 アルコール抽出 $(\mathrm{a}):$ 脱脂粉末を饰の袋に入れドラムカ ンに入れる。ドラムカンの下部には抽出溶液をとりだすコックを つける。メタノールを入れ数日空温放䈯したのちコックから赤い 抽出液をとりたす。この操作を 3 回くり返す( 3 回目には抽出液 はあまり着色しない)。このう法では，収率は（b)にくらべ多少悪 いが大量処理の場合便利である。

3.1 .2 アルコール抽出(b)：脱脂した粉末 $12 \mathrm{~kg}$ を上と下に 口のある $20 l$ のガラスビンに入れ，粉末層を通過したエタノー ル溶液を下の口から $3 l$ のナス型フラスコに導く。ナス型フラス コを加熱して溶媒をふたたびガラスビンの上のロへ蒸留してもど す。このような加熱連続抽出を約 30 時間つうけるとフラスコの 中の抽出液は赫黑となる。

3.1 .3 酶酸エチル抽出：3.1.2(b)で得たアルコール抽出液を 減圧源縮すると半固体になる。水を少し加え減压搌維し，さらに アルコールを除く。最後以流動性が多少ある半固体状とする(水

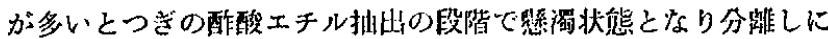
くい)。この半固体の抽壮物に酢酸エチル $1 l$ を朋えときどきか きまぜながら水浴中加熱を約 10 時閒つつける。冷後, 赫照色の

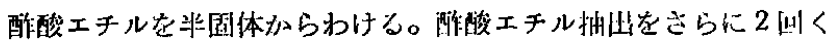
り返与。酢酸エチル層をいっしょにして減正搌縮与ると褐他の油 状物啠が残ま。この油状物を $n$-ヘキサン少量ずつで 8〜10 画洗 う。ヘキサン洗浮後の黑褐色半固体艺心たたび酶酸エチル(500 $\mathbf{m} l$ )に溶がと一部不溶のもの(不純なシキミ酸が主と思われる) が残るので過し，口液に酸洗アルミナ(和光アルミナを希硫酸 で $p \mathrm{H} 4.5$ になるまで洗い，あと祭留水で十分洗って口過し $140^{\circ} \sim 150^{\circ} \mathrm{C}$ で活性化) 40 ～50 g を加えよくかきまぜたのちアル 


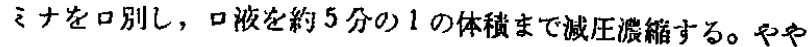
粘椆な黄褐绝溶访が得られ，これを $1 \sim 2$ 日放監すると結晶が析 出する。アニサチンの相絬晶 $2 \sim 2.5 \mathrm{~g}$ が得られる。淮を搌縮 すると，さらに結晶が析出するがアニサチンとデオキシアニサチ ンの混合物である。

酢酸エチルから再結晶を行ない，さらに酸洗アルミナでクロマ トグラフを行なって得たアニサチンを水から再結晶すると $\mathrm{mp}$ $227^{\circ} \sim 228^{\circ} \mathrm{C} * 5$ の針状結晶が得られる。

分析值 C $55.00 \%, \mathrm{H} 6.08 \%$

$\mathrm{C}_{15} \mathrm{H}_{20} \mathrm{O}_{8}$ としての計算值 C $54.87 \%$ ， H $6.14 \%$

\section{2 アニサチンとデオキシアニサチンのภ的}

3.2.1 アルミナクロマトグラフ: アニサチンとデオキシアニ サチンの混合物を䣷酸エチルに溶かし(1g を約 $30 \mathrm{ml}$ の酢酸エ チルに溶かす，酸洗アルミナでクロマトグラつを行なう。酢酸 エチルで溶出すると，デオキシアニサチンがさきに，アニサチン

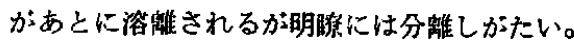

3.2 .2 分別結量: アニサチンとデオキシアニサチンの混合物 䄪 $1 \mathrm{~g}$ を $15 \mathrm{ml}$ の酢酸エチルに溶汃し分別結晶を行なう。ア二 サチンとデオキシアニサチンがほぼ等量の場合は溶解度の小さい アニサチンの方がさきに析出する。酢酸エチルによる再結晶で得 られるアニサチンおよびデオキシアニサチンは，結晶溶媒として $1 \mathrm{~mol}$ の酶酸エチルを盒む(NMR スペクトルで確認)。

分別結晶で得られたデオキシアニサチンを水から再結晶して， mp $237^{\circ} \sim 238^{\circ} \mathrm{C}$ の針状結晶を得る。

分析值 C $57.77 \%, \mathrm{H} 6.60 \%$

$\mathrm{C}_{15} \mathrm{H}_{20} \mathrm{O}_{7}$ としての計算值 C $57.68 \%, \mathrm{H} 6.46 \%$

3.3 ノルアニサチン(II)とノルアニサチノン(III)

過マンガン酸カリウム水溶液 $(5.40 \mathrm{~g} / 100 \mathrm{ml})$ を室温でアニサ チンの 酢酸溶液 $(5.40 \mathrm{~g} / 130 \mathrm{ml})$ に加える。1 夜室温でかきませ たのち，過剩の酸化啨を亜硫酸ナトリウムの水溶液を加えて遥元 する。反応液を減生濃縮すると白色固体が析出する(酭酸ナトリ ウム, 硫酸ナトリウム, 硫酸マンガンなどと考えられる)。白色 固体を口過し，口夜を水で薄め酢酸エチルで抽出する。抽出液は 水, 飽和食㙉水で洗い, 無水硫酸ナトリウムで乾操する。溶媒を 减圧濃縮すると淡黄色の油状物質 $(4.32 \mathrm{~g})$ が得られ, シリカゲル $(80 \mathrm{~g})$ でカラムクロマトグラフを行なう。

酶酸エチルークロロホルム(1:3, 体栍比)で溶出すると, はじ めの溶出液(約 $100 \mathrm{~m} l)$ 加ら結晶状物苃 $(0.92 \mathrm{~g})$ が得られ, ク口 ロホルムで再結鼠するとノルアニサチノン(I), mp $213^{\circ} \sim 215^{\circ}$ Cの無色柱状結晶が得られる。

IR: $\nu_{\max }^{\mathrm{CHCl}_{3}} 3500,1831,1789,1754 \mathrm{~cm}^{-1}$

分析值 C $56.43 \%, \mathrm{H} 5.76 \%$

$\mathrm{C}_{14} \mathrm{H}_{16} \mathrm{O}_{7}$ としての計算值 C $56.75 \%$, H $5.44 \%$ つうく溶出液 $(280 \mathrm{ml})$ から絬晶状物質 $(1.29 \mathrm{~g})$ が得られ, クロ ロホルムーエーテルから再結晶するとノルアニサチン(I)， $\mathrm{mp}$ $163^{\circ} \sim 164^{\circ} \mathrm{C}$ の槃色柱状絬品が得られる。

IR: $\nu_{\max }^{\mathrm{CHCl}_{3}} 3460,1832,1778 \mathrm{~cm}^{-1}$

分析値 C $56.27 \%, \mathrm{H} 6.13 \%$

$\mathrm{C}_{14} \mathrm{H}_{18} \mathrm{O}_{7}$ としての計算値 C $56.37 \%, \mathrm{H} 6.08 \%$

3.4 ノルアニサチン炭酸エステル(IV)

I $(300 \mathrm{mg})$ をテトラヒドロフラン $(5 \mathrm{ml})$ とピリシン $(0.5 \mathrm{ml})$ に

*5 䤙点は未補正值である。
溶かした溶液を $0^{\circ} \mathrm{C}$ に冷し，ホスゲンガスを通ずるとはしめ白 䙳を㥕し, 白色沛殿が析出する。45 分闑ホスゲンを通じたのち, 溶媒の大部分を減压で除去し，残留物を水で薄めると白色結晶 (200 mg)が析出する。クロロホルム酶酸エチルから再結晶する と炭酸エステル(N), mp $236^{\circ} \sim 238^{\circ} \mathrm{C}$ の白色針状結晶が得られ る。

IR: $\nu_{\max }^{\mathrm{KBr}} 3520,1820,1795,1770 \mathrm{~cm}^{-1}$

分析值 C $55.71 \%, \mathrm{H} 5.00 \%$

$\mathrm{C}_{15} \mathrm{H}_{16} \mathrm{O}_{8}$ としての計其值 C $55.55 \%, \mathrm{H} 4.97 \%$

3.5 ケトアルデド(V)

四酥酸鉛の酢酸溶液 $(0.066 \mathrm{~mol} / l, 17 \mathrm{~m} l)$ を 1 の $70 \%$ 含水 酢酸溶液 $(312 \mathrm{mg} / 6 \mathrm{ml})$ に滴下する。室温で 4 時間放置, エチン ングリコール(約 $20 \mathrm{mg}$ )を加えたのち, $50^{\circ} \sim 60^{\circ} \mathrm{C}$ て娍压沙維す る。牫留物に水を加えて, 釄酸エチルで抽出, 抽出液を水, 和 食塭水で洗い，無水硫酸ナトリウムで乾燥する。溶媒を減圧で除 去すると無色油状物質(約 $300 \mathrm{mg}$ )が得られ，テトラヒドロフラ ンで結晶化するとケトアルデヒド(V)，mp 191〜 192。 Cの無色 板状結晶 $(90 \mathrm{mg})$ を得る。

IR: $\nu_{\max }^{\mathrm{THF}} 1847,1767,1725,1712 \mathrm{~cm}^{-1}$

分析値 G $56.88 \%$, H $5.36 \%$

$\mathrm{C}_{14} \mathrm{H}_{10} \mathrm{O}_{7}$ としての計算值 C $56.75 \%$, H $5.44 \%$

3.6 ケト酸(VI)

3.6.1 ケトアルデヒド(V)から: 過マンガン酸カリウムの 10 $\mathrm{N}$ 硫酸溶液 $(140 \mathrm{mg} / 20 \mathrm{ml})$ を, $\mathrm{V}(200 \mathrm{mg})$ の酢酸 $(5 \mathrm{ml})-10 \mathrm{~N}$ 硫 酸 $(5 \mathrm{ml})$ 浚液へ室温でかきまぜながら滴下する。反応洨の褐色が 5,6 分間持続しだしたら過マンガン酸カリゥム溶液の滴下をや らる。反応液をエーテル抽出し, 抽出液は水, 愒和食壏水で洗い 無水硫酸ナトリウムで乾燥する。溚媒を減圧除去して得られる等 色油状物筫 $(170 \mathrm{mg})$ を酢酸エチルークロロホルムから結晶化する と,ケト酸 ( I ) $\mathrm{mp} 152^{\circ} \sim 154^{\circ} \mathrm{C}$ の白色針状結晶が得られる。

IR: $\nu_{\max }^{\mathrm{KBr}} 1828,1751,1730,1715 \mathrm{~cm}^{-1}$

分析値 C $53.78 \%, \mathrm{H} 5.04 \%$

$\mathrm{C}_{14} \mathrm{H}_{16} \mathrm{O}_{8}$ としての㖕算值 C $53.84 \%$, H $5.16 \%$

滴定によりこの物㿽は $p K_{f}^{\prime}$ 值 4.29 (水中)をむつ一㫫基酸で あることがわかった。

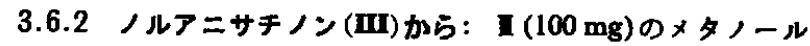
溶液 $(4 \mathrm{ml})$ に過 $\exists$ ウ素酸 $(200 \mathrm{mg})$ の水溶液 $(3 \mathrm{ml})$ を加える。室温

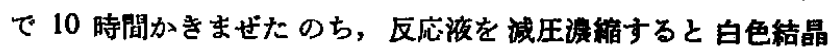
(40 mg)が析出する。結晶をロ取して, 䣫酸エチルークロロホルム からら再結晶すると無色針状結晶, mp 152〜 154 ${ }^{\circ} \mathrm{C}$ が得られる。 この物質は 3.6.1 で得られたケト酸(U)と, 赤外吸取スペクト ル，混融により一致することが確認された。なお口湤からもエー テル抽出によりり約 $40 \mathrm{mg}$ の同物貿が得られる。

\section{7 ノルアニサチンモノアセタート(VI)}

I $(80 \mathrm{mg})$ のピりシン溶液 $(1 \mathrm{ml})$ に然水酷酸 $(0.2 \mathrm{ml})$ を加える。

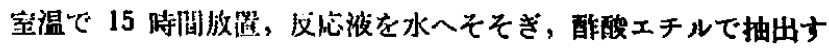
る。抽出液を水，飽和食塭水で洗い無水硫酸ナトリゥムで䡉柏 後, 溶媒を除去一るを白他結晶が得られる。これをク口ロホルムー エーテルから再結晶するとノルアニサチンモノアセタート(尚)， $\mathrm{mp} 186^{\circ} \sim 188^{\circ} \mathrm{C}$ 方得られる(柱状絬晶, $50 \mathrm{mg}$ )。

IR: $\nu_{\max }^{\mathrm{KBr}} 3400,1820,1770,1725 \mathrm{~cm}^{-1}$

この物躓は,重クロロホルム中の NMRスペクトル(2.08 ppm, 
3H)により，アセチル基が1個入っていることがわかった。 分析值 C $56.56 \%$, H $5.80 \%$

$\mathrm{C}_{16} \mathrm{H}_{20} \mathrm{O}_{3}$ としての計算值 C $56.46 \% ， \mathrm{H} 5.92 \%$

3.8 ノルアニサチン (II) 功らルアニサチノン (III)

I $(250 \mathrm{mg})$ の酷酸溶液 $(10 \mathrm{ml})$ K, ク口ム酸酷酸溶液 $(200 \mathrm{mg} /$ $1 \mathrm{ml}$ ) を加える。室温 24 時間放置後, 亚硫酸ナトリウムの水溶 液を加え，過剩の酸化郬を僄元する。反応液を水にそそぎ，酶酸 エチルで抽出。抽出液は水, 飽和食塩水で洗い, 無水硫酸ナトリ ウムで乾燥する。溶媒を減任濃縮すると 淡緑色の 油状物質 (300 $\mathrm{mg})$ が得られる。この油状物贊をクロロホルムでシリカゲル $(3 \mathrm{~g})$ を用いてクロマトグラフを 行なう。はじめの溶出液 $(30 \mathrm{ml})$ から 白色結晶 $(84 \mathrm{mg})$ が得られ，クロロホルムがら再結晶すると，白 色柱状結晶, $\mathrm{mp} 213^{\circ} \sim 215^{\circ} \mathrm{C}$ を得る。この物質は混融, IR $K$ よりノルアニサチノン( $\mathbf{M})$ と同定された。

つぎの溶出液から得られる白色結晶 $(90 \mathrm{mg})$ を酶酸エチルークロ ロホルムから再結晶すると白色針状結晶, mp $152^{\circ} \sim 154^{\circ} \mathrm{C}$ が得 られる。この物質は混融，IR により，ケト酸(U)と同定された。

\section{9 ブロムノルアニサチノン(VII)}

真素 $(160 \mathrm{mg})$ の醀酸 $(1 \mathrm{ml})$ 溶液を，48\% 莫化水素酸の 2 滴を 含んた I $(188 \mathrm{mg})$ の酢酸 $(10 \mathrm{ml})$ 溶液に加える。反応液を湯浴上 $70^{\circ} \mathrm{C}$ で 1 時間半加熱。溶媒を減圧濃縮すると白色結晶が得られ る。この物筫をシリカゲルクロマトグラフにより精嫩(クロロホ ルムで溶出)。アセトンーメーテルから再結晶すると,ブロムノル アニサチノン(V), mp $207^{\circ} \sim 211^{\circ} \mathrm{C}$ (昇華)が 白色柱状結晶(150 mg）として得られる。

IR: $\nu_{\max }^{\mathrm{KBT}} 1827,1774,1767$ (夙) $\mathrm{cm}^{-1}$

分析值 G $44.76 \%, \mathrm{H} 4.07 \%$

$\mathrm{C}_{14} \mathrm{H}_{15} \mathrm{O}_{7} \mathrm{Br}$ としての計算值 G $44.81 \%, \mathrm{H} 4.03 \%$

3.10 プロムノルアニサチノン(ViI)からノルアニサチノン (III)

Vii $(90 \mathrm{mg})$ の酢酸溶液 $(5 \mathrm{ml})$ に亜鉛 $(100 \mathrm{mg})$ を加え, 1 夜室温 でかきまぜたのち，1時間油浴上で還流する。反応液を放冷して 口過し，口液を減圧漂縮する。残留物を醀酸エチルに溶かし，水， 飽和食塩水で洗ったのち，無水硫酸ナトリウムで乾燥。溶媒を減 圧除去すると白色結晶が得られ，それをクロロホルムで再結晶す ると白色柱状結晶, $\operatorname{xap} 213^{\circ} \sim 215^{\circ} \mathrm{C}$ が得られる。この物質はIR， 混融によりノルアニサチノン（I）と同定された。

\subsection{1 メチルコハク酸}

アニサチン ( I ) (500 mg)を $6 \mathrm{~N}$ 硫酸 $(25 \mathrm{ml})$ 《㗭濁し, 水浴中 $80^{\circ} \sim 90^{\circ} \mathrm{C}$ に加温しつつ, クロム酸水溶液 $(2 \mathrm{~g} / 22 \mathrm{ml})$ を約 5 時 間で $14 \mathrm{ml}$ ，加える。反応の進行とともにアニサチンは次第に溶 けるが，反応の終り頃に一部不溶物が析出する(反応後の溶液は 赤緑色)。反底溶液を減圧蒸留すると留出液は酸性で, 酷酸が検 出される(ペーパークロマトグラフおよび酢酸アンモニウムで確 認)。残留物を少量の水に溶かし，エーテルで 8 時間連続抽出す る。エーテル層を無水硫酸ナトリウムで乾燥後, 減圧乾固すると 黄色油状物 (300 mg)が得られる。この油状物をふたたびエーテル
$(50 \mathrm{ml})$ に溶かし, 飽和崖酸水素ナトリウム水溶液 $(10 \mathrm{ml}$ で 2 回)で抽出する。炭酸水素ナトリウム溶液を $4 \mathrm{~N}$ 酼酸で酸性にし て，エーテルで連続抽出する。エーテル層を無水硫酸ナトリウ ムで乾燥後, 減王濃縮すると, 油状物 $(140 \mathrm{mg})$ が得られる。この 酸性油状物をクロロホルムー酢酸エチル(7: 1, 体積比)でシリカ ゲルを用いクロマトグラフを行なう。クロロホルムー醀酸エチル (6:1) で溶離されてくる部分から, 白色固体(約 $40 \mathrm{mg}$ )が得られ る。この白色固体の質量スペクトルはメチルコハク酸(合成品)と 完全に一致した。

白色固体の一部を少量のメタノールに溶かし，炭酸水素ナトリ ウム水溶液で中和する。減圧浱縮するとナトリウム塩が得られ る(約 $50 \mathrm{mg}$ )。ナトリウム塩を少量の水に溶かし, 英化 $p$-ブロ

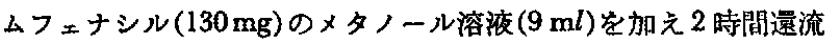
する。放冷すると色色結晶を生ずる。結晶を口過し四塩化炭素か ら再結晶すると無色針状結晶, mp $136.5^{\circ} \sim 138^{\circ} \mathrm{C}$ が得られる。

分析值 C $48.20 \%, H 3.80 \%$

$\mathrm{C}_{21} \mathrm{H}_{18} \mathrm{O}_{6} \mathrm{Br}_{2}$ としての計算值 C $47.93 \% ， \mathrm{H} 3.45 \%$

この物質がメチルコハク酸の p-ブロムフェナシルエステルで あることは，合成品との比較(赤外吸収スペクトル)で確認した。

3.12 岸聡エステル(IV)のア七チル化

W $(110 \mathrm{mg})$ のピリシン $(2 \mathrm{ml})$ と無水酷酸 $(0.4 \mathrm{ml})$ の溶液を水浴 上 $70^{\circ} \mathrm{C}$ で 3 时間加熱する。溶媒のほとんどを減压で除去し，残 留物に少墨の水を加光ると固化する。

このるのは，赤外吸取スペクトルで原料と宽全に一致した。

\subsection{3 岸酸エステル(IV)のクロム酸酸化}

IV $(100 \mathrm{mg})$ を酰酸 $(20 \mathrm{~m} l)$ に溶かし，クロム酸醉酸溶液 $(70 \mathrm{mg} /$ $5 \mathrm{ml}$ ) 加え, 水浴上で $60^{\circ} \sim 70^{\circ} \mathrm{G}$ に 3.5 時間加温する。反応 液を水にそそき酶酸エチル抽出する。抽出液を水，飽和食熄水で 洗い無水硫酸ナトリウムで乾燥。溶媒を隇圧濃繀すると結晶 $(90$ mg)が得られる。この物資は赫外叹スペクトルで原料と一致す る。

\subsection{II, III, VII の四酭酸站简定}

試料 $3 \sim 6 \mathrm{mg}$ 老精科し，四酢酸鉛の標準溶液 $(9.00 \mathrm{ml})$ と水 $(1.00 \mathrm{~m} l)$ に溶かす。反応液から $1.00 \mathrm{ml}$ をとり, 飽和酢酸ナト リウム水溶液 $(1 \mathrm{~m} l)$ 人そそき， $10 \%$ ヨウ化カリウム水溶液 $(2 \mathrm{~m} l)$ を加える。遊離するヨウ素をチオ硫酸ナトリウム標隻溶液で滴定 し, 同様に調整して行なわれた白紙試験との比較により, 四酢酸 鉛の消費量安計算した。

[結果]

I： 2 時間 $(0.84 \mathrm{~mol}), 9$ 時間 $(0.90 \mathrm{~mol}), 30$ 時間 $(1.02 \mathrm{~mol})$

II : 2 時閔 $(0.08 \mathrm{~mol}), 6$ 時閻 $(0.10 \mathrm{~mol}), 50$ 時閪 $(0.11 \mathrm{~mol})$

VI : 3 時間 $(0.00 \mathrm{~mol}), 20$ 時間 $(0.00 \mathrm{~mol})$

終りに，との研究の研究貿の一部は NIH 研究費, 交部省科学 研究費和よび東洋レーヨン科学技術研究期成金によるるのであ り，ととに厚く感謝します。

(1964 年 10 月, 天然有機化合物討諭会; 1965 年 4 月, 日本 化学会第 18 年会発表) 